\title{
Corporal Composition and Characteristics of Carcass of Araucano Creole Lambs
}

\author{
Composición Corporal y Características de la Carcasa de Corderos Criollos Araucanos
}

\author{
"Silvana Bravo; **Macarena Fabres; **B Berta Schnettler \& **Néstor Sepúlveda
}

BRAVO, S.; FABRES, M.; SCHNETTLER, B. \& SEPÚLVEDA, N. Corporal composition and characteristics of carcass of Araucano creole lambs. Int. J. Morphol., 28(4):1107-1111, 2010.

SUMMARY: Once livestock is slaughtered the carcass of body obtained represents the main commercial product, and is valued in terms of quality. The aim of this work was to characterize and evaluate the carcasses of Araucano creole lambs. Thirteen Araucano lambs were slaughtered at $221 \pm 15$ days of age weighing $32 \pm 2 \mathrm{Kg}$. The hot carcass was weighed and after 24 hours at $4^{\circ} \mathrm{C}$ the cold carcass was weighed. The characteristics of conformation, fat cover and regional composition of the carcass were evaluated according to Chilean regulation standards. The tissue composition of the back was also determined, in its three components (muscle, bone and fat). The commercial yield of the carcass was $51.14 \%$ and losses due to dehydration of the carcass were recorded at $3 \%$. The carcasses were characterized as $77 \mathrm{~cm}$ long and $24 \mathrm{~cm}$ wide at chest level. According to the thickness of muscle and fat, they were qualified as lean carcasses and the area of Longissimus dorsi muscle was an average of $15 \mathrm{~cm}^{2}$. The regional composition of the carcass presented a high percentage of lean pieces, forequarter $(38.9 \%)$ and let (28.9\%) with 59.5\%) of the regional composition being the first category pieces with a high commercial value. The carcasses of the Araucano creole lambs were classified as heavy, of average length with a yield greater than $50 \%$ of good conformation and average fat cover. These characteristics indicate that this cattle can be defined as an attractive genetic resource for meat production in Southern Chile.

KEYWORDS: Ovines; Chile; Carcass measurements.

\section{INTRODUCTION}

The carcass or canal is defined as the body of the animal, bled, skinned and gutted separating the head at the level of the occipito-atloid joint and without members which are severed at the level of carpo metacarpian and tarso metatarsian joints. This includes the tail, the pillars, the fleshy peripheral part of the diaphragm as well as the testicles, kidneys and fat that covers these, as well as the fat in the pelvic cavity. The carcass constitutes an important commercial objective, of the butchering possibilities of the live animal. Its quantitative and qualitative characteristics basically depend on the genotype of the animal and the production system used. Undoubtedly, the environment, breed characteristics and the different geographical conditions the type of animal with respect to age and weight at the time of slaughter, define different commercial types of the carcass.

For commercial value the carcass must be studied for quality given by its characteristics and which importance affords it greater acceptance and the best price (Alcalde \& Horcada, 2009; Sañudo et al., 1998).

According to the above and growing interest worldwide to evaluate local zoogenetic resources, invaluable germplasm that would allow the preservation of biodiversity of animal production (Rodas et al., 2006), the objective of

\footnotetext{
* Alumna del Doctorado en Ciencias mención Biología Celular y Molecular Aplicada. Facultad de Ciencias Agropecuarias y Forestales, Universidad de La Frontera, Temuco, Chile.

** Departamento de Producción Agropecuaria, Facultad de Ciencias Agropecuarias y Forestales, Universidad de La Frontera, Temuco, Chile.

Este estudio fue realizado en el Centro de Tecnología y Calidad de Carne del Instituto de Agroindustria de la Universidad de La Frontera, con aportes del Proyecto FIA-PIT-2007-0200: Establecimiento de un programa asociativo para el desarrollo tecnológico en la industria de la carne nacional y del Proyecto Núcleo Genético Ovino Araucano (Convenio Ministerio de Agricultura de Chile, INDAP, Universidad de La Frontera).
} 
this investigation is to evaluate the characteristics of the carcass of creole Araucano ovines kept in an extensive production system based on natural pasture in the central valley of the Araucanía Region, Chile. The creole sheep is mainly present in the Region of the Araucanía and used for double producing purposes, (meat and wool), namely exploited by the Mapuche indigenous people in extensive productive systems (Sepulveda, 1999; Bravo \& Sepulveda, 2010).

\section{MATERIAL AND METHOD}

Location of the study. The study was carried out at the ovine module of the Estación Experimental Maquehue (EEM) and the Technology and Meat Quality Laboratory of the AgroIndustrial Institute of the Universidad de La Frontera, Chile.

Animals and their Management. 13 Araucano lambs of $32+2 \mathrm{~kg}$ of live weight at the time of slaughter (LWS) and $221+15$ days of age. The lambs were raised with their mothers from the lambing (August of 2008) up to 120 days of age. From birth up to the date of slaughter (March of 2009) all lambs were kept in natural pasture of the central valley of the region of the Araucanía that receive maintenance fertilization during the month of August and sporadic gravitational irrigation during the summer months.

Slaughter. Slaughter of the animals was carried out at the Lautaro slaughtering plant (at a distance of $46 \mathrm{~km}$ from the EEM). Following a 16-hour wait with water access the ovines were sacrificed prior electrical stunning. Subsequently the hot carcass (HWC) of the animals was weighed, and after 24 hours at $4^{\circ} \mathrm{C}$ the cold carcass was weighed (WCC).

Carcass measurements. In the cold carcass of the lambs we determined conformation using the morphological measurements: total length of carcass (LC), length of leg, rump width and depth of thorax using a metric tape and compass according to methodology described by Fisher \& de Boer (1994) and Ruiz de Huidobro et al. (2000). With this information and the weight of the carcasses commercial yield (WCC* 100/PVS) and compact index of the carcass (WCC/LC) were determined.

Thickness of muscle and fat were determined at the level of the 12th rib $11 \mathrm{~cm}$ from the dorsal medial line of the carcass, and the thickness of dorsal fat was determined by depth of subcutaneous fat or coverage over 13th rib $4 \mathrm{~cm}$ from the medial line, using a caliper according to Ruiz de Huidobro et al. methodology. Subsequently the carcass was cut along the vertebral column which resulted in equal parts.

Rib eye area was realized in the same manner as the muscle and fat measurement, at the level of the $12^{\text {th }}$ rib in the transversal section of the Longissimus dorsi muscle, labeling the muscle contour on millimetric paper; the surface in $\mathrm{cm}^{2}$ was determined (Ruiz de Huidobro et al.).

The left half carcass was weighed and commercial cuts were carried out according to the Chilean commercial standard 1595. Of 2000 (INN 2000) in four pieces: legs, shanks, ribs and front quarters (Fig. 1). Subsequently commercial pieces were weighed, vacuum packed and frozen at $-20^{\circ} \mathrm{C}$. To determine the tisular composition (muscle/fat/bone), the forequarter was unfrozen and the anterior left member (back) was dissected according to Colomer-Rocher et al. (1988) and Vergara \& Gallegos (2000) methodology. Determining its tisular composition.

With this information the percentage of meat, bone and fat was calculated as well as the muscle/fat and muscle/bone association.

Statistical analysis. Values of each variable analyzed were registered using Microsoft Excell (Windows Vista TM). A descriptive statistical analysis was carried out of all variables through the statistical program SPSS 17.0.

\section{RESULTS AND DISCUSSION}

Characteristic of the carcass. Table I shows the main descriptive statistics corresponding to the characteristics of the Araucano creole lamb carcass.

In sheep a parameter has a limited variability when its variation coefficient is less than $10 \%$, a medium variability when it is between $15 \%$ and $20 \%$, and a very important variability when it is above $20 \%$ (Alcalde, 1995).

Of the characteristics evaluated only $30 \%$ showed a medium to high variability, and the remaining $70 \%$ presented a low variability which demonstrates that homogeneity exists of the variables analyzed associated to the carcass quality.

According to Ruiz de Huidobro et al. and ColomerRocher et al., the carcasses of Araucano lambs were classified as heavy carcasses (over $13 \mathrm{~kg}$ ) well conformed and of medium fat grade (Fig. 2). 
Commercial yield of the Araucano lamb carcass with a live weight of $32 \pm 2 \mathrm{~kg}$, was $51.14 \%$. Loss for dehydration defined as the relation between the weight of the hot carcass and cold carcass following 24 hours at $4^{\circ} \mathrm{C}$, reached an average of $3 \%(0.5 \mathrm{Kg})$. Reported losses by other authors were approximately $2 \%$ (Alcalde \& Horcada).
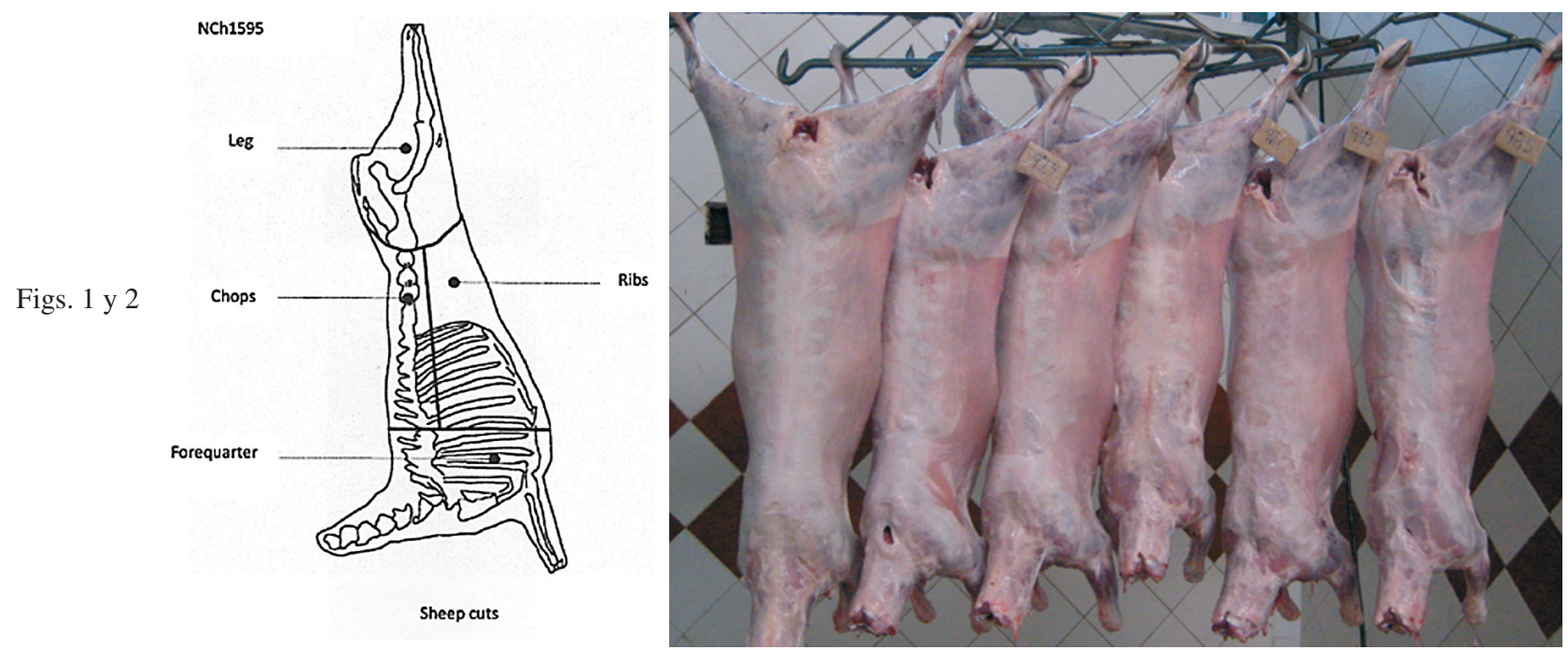

Table I. Descriptive statistic of the characteristics of the carcass of Araucano creole lambs.

\begin{tabular}{|c|c|c|c|c|c|c|}
\hline Characteristics of the carcass & $\mathbf{n}$ & Medium & SD & $\mathrm{CV}$ & Minimum & Maximum \\
\hline \multicolumn{7}{|l|}{ Conformation and fat } \\
\hline Weight of hot carcass (Kg) & 13 & 16,38 & 1,12 & 6,81 & 14,90 & 18,70 \\
\hline Weight of cold carcass $(\mathrm{Kg})$ & 13 & 15,88 & 1,12 & 7,07 & 14,50 & 18,00 \\
\hline Length of carcass $(\mathrm{cm})$ & 13 & 77,08 & 5,51 & 7,15 & 68,00 & 84,50 \\
\hline Length of leg (cm) & 13 & 27,16 & 0,91 & 3,34 & 26,00 & 28,50 \\
\hline Rump width (cm) & 13 & 14,65 & 1,28 & 8,74 & 13,00 & 18,00 \\
\hline Depth of thorax (cm) & 13 & 24,92 & 1,04 & 4,16 & 23,00 & 26,00 \\
\hline Thickness of dorsal fat (mm) & 13 & 1,19 & 0,22 & 18,88 & 0,90 & 1,50 \\
\hline Thickness of muscle and fat (mm) & 13 & 6,53 & 1,01 & 15,36 & 5,35 & 8,00 \\
\hline Rib eye area $\left(\mathrm{cm}^{2}\right)$ & 13 & 15,00 & 2,69 & 17,92 & 12,04 & 21,41 \\
\hline Commercial yield of the carcass $(\%)$ & 13 & 51,14 & 2,49 & 4,87 & 44,19 & 53,07 \\
\hline Compactness of the carcass $(\mathrm{Kg} / \mathrm{cm})$ & 13 & 0,27 & 0,02 & 6,30 & 0,24 & 0,30 \\
\hline \multicolumn{7}{|c|}{ Regional composition of the left carcass } \\
\hline Leg $(\%)$ & 13 & 28,88 & 4,93 & 17,06 & 22,58 & 35,22 \\
\hline Ribs (\%) & 13 & 14,68 & 1,90 & 12,91 & 12,48 & 17,58 \\
\hline Chops $(\%)$ & 13 & 15,96 & 3,06 & 19,15 & 13,16 & 19,58 \\
\hline Forequarter $(\%)$ & 13 & 38,86 & 1,75 & 4,51 & 36,25 & 41,98 \\
\hline \multicolumn{7}{|l|}{ Tisular composition of the back } \\
\hline Meat (\%) & 13 & 60,39 & 1,96 & 3,24 & 57,42 & 63,35 \\
\hline Bone $(\%)$ & 13 & 22,73 & 1,57 & 6,92 & 19,63 & 25,78 \\
\hline Total fat $(\%)$ & 13 & 16,28 & 2,22 & 13,65 & 11,86 & 18,91 \\
\hline Meat/fat & 13 & 3,79 & 0,67 & 17,70 & 3,04 & 5,33 \\
\hline Meat/bone & 13 & 2,67 & 0,23 & 8,57 & 2,23 & 3,13 \\
\hline
\end{tabular}


Thickness of dorsal fat (TDF), is a characteristic used to estimate the quality of the carcass and in several meat producing animal species an important correlation with carcass fat has been observed (Hedrick, 1983). In this study an average TDF of $1.19 \pm 0.2 \mathrm{~mm}$ was low to that presented by Abdullah \& Rasha (2008) and Perez et al. (2007), in Awassi and Suffolk lambs respectively.

Thickness of muscle and fat of the Araucano lambs was of $6.53 \pm 1.0$ value that qualifies as magro, as it is less than $7 \mathrm{~mm}$. Kremer et al. (1998), considered that a certain amount of coverage fat is necessary to protect the carcass from the cold of the refrigeration chambers, that it should at the same time, not exceed $12 \mathrm{~mm}$, since this would imply an excess of fat that must later be eliminated.

The rib eye area (REA) is directly related with the size of the Longissimus dorsi muscle, and the chops obtained. In this study an average of REA of $15 \mathrm{~cm}^{2}$ was obtained.

The percentile distribution of the different pieces or areas that comprise the carcass and the relation between the amount of muscle, bone and fat are important points at the time of assessing the quality of the sheep carcass. The composition of the left carcass in Araucano lambs presented a high percentage of lean cut; forequarter (38.9\%) and leg (28.9\%). Corresponding to $59.5 \%$ of the regional composition to cuts with high value commercial (Bianchi et at., 2006)
According to Robelin (1986) an ideal carcass is one that has a high percentage of muscle and sufficient infiltrated fat and limited coverage fat.

In Araucano lambs according to the tisular composition of the back, recommended methodology as a predictor for total tisular composition of the carcass for presenting elevated coefficients of the correlation with the composition of the carcass (Vergara \& Gallego) allowed us to obtain $60.4 \%$ of muscle tissue, $22.7 \%$ of bone and $16.3 \%$ of adipose tissue. These results are similar to Carrasco et al. (2009) in lambs fed on grazing, indicating that a lower fat deposit may be associated with limited energy in the diet of the animals.

According to this work we may conclude that the Araucano lambs evaluated present heavy carcasses, medium length, with a yield higher than $50 \%$, are well conformed and medium fat. Approximately $60 \%$ of their regional composition corresponds to first category commercial cuts. These characteristics allow the classification of this breed as an attractive zoogenetic resource for meat production in the South of Chile.

This study is the first step realized in the characterization of the carcass of this breed with the aim of promoting further research to differentiate additional products.

BRAVO, S.; FABRES, M.; SCHNETTLER, B. \& SEPÚLVEDA, N. Composición corporal y características de la carcasa de corderos criollos Araucanos. Int. J. Morphol., 28(4):1107-1111, 2010.

RESUMEN: Una vez sacrificados los animales de abasto se obtiene la carcasa o canal, ésta representa el principal producto comercial y se valora en términos de calidad. El objetivo de este trabajo fue caracterizar y valorar las carcasas obtenidas de corderos criollos Araucanos. Fueron sacrificados 13 corderos Araucanos de $32 \pm 2 \mathrm{Kg}$ de peso vivo y de $221 \pm 15$ días de edad. Se pesó la carcasa caliente, y luego de 24 horas a $4^{\circ} \mathrm{C}$ se pesó la carcasa fría. Se evaluó en el laboratorio las características de conformación, engrasamiento de la carcasa y se evaluó la composición regional de la carcasa de acuerdo a la norma chilena. Determinándose también la composición tisular de la espalda en sus tres componentes (músculo, hueso y grasa). El rendimiento comercial de la carcasa fue de un 51,14\% y las pérdidas por deshidratación de la carcasa fueron de un 3\%. Las carcasas se caracterizaron por tener un largo de $77 \mathrm{~cm}$ y un ancho a nivel del tórax de $24 \mathrm{~cm}$. Según el espesor de músculo y grasa (GR) fueron calificadas como carcasas magras y el área del músculo longísimo del dorso alcanzó un promedio $15 \mathrm{~cm}^{2}$. La composición regional de la carcasa presentó un alto porcentaje de piezas magras: cuarto delantero $(38,9 \%)$ y pierna $(28,9 \%)$, correspondiendo el $59,5 \%$ de la composición regional a piezas de primera categoría, de alto valor comercial. Las carcasas de corderos criollos Araucanos se clasificaron como pesadas, de longitud media, con un rendimiento superior al $50 \%$, de buena conformación y engrasamiento medio, características que permiten definir a este ovino como un atractivo recurso zoogenético para la producción de carne en la zona sur de Chile.

PALABRAS CLAVE: Ovinos; Chile; Medición de la Carcasa.

\section{REFERENCES}

Abdullah, Y. A. \& Rasha, I. Q. Carcass characteristics of Awassi ram lambs slaughtered at different weights. Livest. Sci., 117:165-75, 2008.
Alcalde, M. Calidad de carne en canales ovinas ligeras españolas Segureñas. Tesis doctoral. Universidad de Zaragoza, España, 1995. 
Alcalde, M. \& Horcada, A. La canal ovina. En: Ovinotecnia: Producción y Economía en la especie ovina. Sañudo, A. C. \& Cepero, B. R. (Ed.). Zaragoza, Prensas Universitarias de Zaragoza, 2009.

Bianchi, G.; Garibotto, G.; Feed, O.; Betancur, O.; Franco, J. Efecto del peso al sacrificio sobre la calidad de la canal y de la carne de corderos Corridale puros y cruza. Arch. Med. Vet., 38:161-5, 2006.

Bravo, S. \& Sepúlveda, N. Índices zoométricos en ovejas criollas Araucanas. Int. J. Morphol., 28:489-95, 2010.

Carrasco, S.; Ripoll, G.; Panea, B.; Álvarez, J. \& Joy, M. Carcass tissue composition in light lambs: Influence of feeding system and prediction equations. Livest. Sci., 126:112-21, 2009.

Colomer-Rocher, F.; Delfa, R. \& Sierra, I. Métodos de normalizados para el estudio de los caracteres cuantitativos y cualitativos de las canales ovinas producidas en el área mediterránea, según los sistemas de producción. En: Métodos normalizados para el estudio de los caracteres cuantitativos y cualitativos de las canales caprinas y ovinas. Cuadernos INIA, 17:19-41, 1988.

Fisher, A. V. \& de Boer, H. The EAAP standard method of sheep carcass assessment. Carcass measurements and dissection procedures. Report of the EAAP working group on Carcass Evaluation, in cooperation with the CIHEAM Instituto Agronomico Mediterraneo of Zaragoza and the CEC Directorate General for Agriculture in Brussles. Livest. Prod. Sci., 38:149-59, 1994.

Hedrick, H. Methods of estimating live animal and carcass composition. J. Anim. Sci., 57:1316-27, 1983.

INN, Instituto Nacional de Normalización, Chile. Cortes de carne de ovino. NCh1595. Of. 2000. Chile, 2000.

Kremer, R.; Barbato, G.; Roses, L.; Rista, L.; Castro, L.; Herrera, B.; Neirotti, V.; Sienra, L.; López, B.; Perdigon, F.; Sosa, L.; Larrosa, J. Evaluación de cruzamientos terminales para la producción de carne ovina. Revista ARU, (3) 4:18-24, 1998.

Pérez, M. P.; Maino, M. M.; Kôbrich, G. C.; Morales, S. M. S. \& Pokniak, R. J. Efecto del peso de sacrificio y sexo sobre la canal de corderos lactantes del cruce Suffolk Down x Merino Precoz Alemán. Rev. Cient., 17:621-6, 2007.
Robelin, J. Growth of adipose tissues in cattle: partitioning between depots, chemical composition and cellularity. A review. Livest. Prod. Sci., 14:349-64, 1986.

Rodas, A.; Vergara, J.; Arenas de Moreno, L.; Huerta, N.; Pirela, M. Características al sacrificio, rasgos de la canal y rendimiento carnicero de novillos criollo Limonero sometidos a suplementación durante la fase de ceba a pastoreo. Rev. Cient., 16:371-80, 2006.

Ruiz de Huidobro, F.; Cañeque, V.; Onega, E.; Velasco, S. Morfología de la canal Ovina. En: Metodología para el estudio de la calidad de la canal y de la carne en rumiantes. Cañeque, V. \& Sañudo, C. (Ed.). Madrid, Instituto Nacional de Investigación y Tecnología Agraria y Alimentaria, 2000.

Sañudo, C.; Sanchez, A. \& Alfonso, M. Small ruminant production system and factors affecting lamb meat quality. Meat Sci., 49:29-64, 1998.

Sepúlveda, N. Características productivas de los rebaños ovinos de ganaderos indígenas Mapuches de la IX Región de Chile. El Arca, 3:47-52, 1999.

Vergara, H. \& Gallego, L. Composición de la canal Ovina. En: Metodología para el estudio de la calidad de la canal y de la carne en rumiantes. Cañeque, V. \& Sañudo, C. (Ed.). Madrid, Instituto Nacional de Investigación y Tecnología Agraria y Alimentaria, 2000.

\section{Correspondence to:}

Prof. Dr. Nestor Sepúlveda

Departamento de Producción Agropecuaria

Facultad de Ciencias Agropecuarias y Forestales

Universidad de La Frontera

Temuco, CHILE

Email: nestor@ufro.cl

Received : 30-08-2010

Accepted : 29-09-2010 
